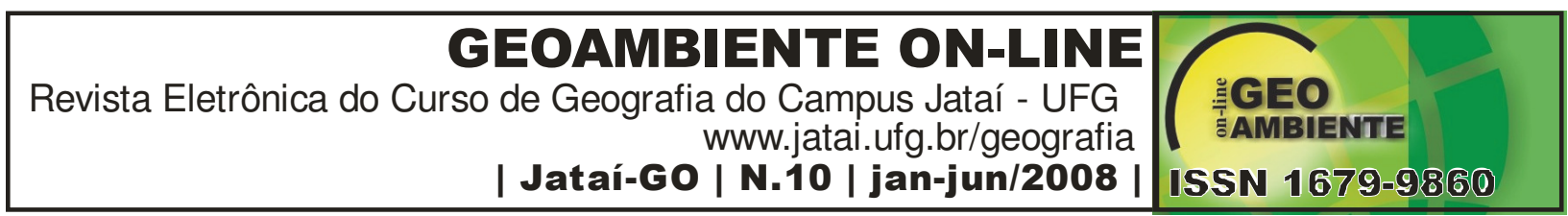

\title{
GESTÃO AMBIENTAL NA RECUPERAÇÃO DA RODOVIA SC-425 TRECHO BR-470/OTACÍLIO COSTA-SC/BR-282
}

Luiz Miranda $^{1,2}$, Valter Antonio Becegato ${ }^{3}$, Olívia Aparecida Rodolfo Figueiredo ${ }^{3}$, Sideney Becker Onofre $^{4}$, William César Polônio Machado ${ }^{5}$, Gabriela Salami ${ }^{6}$

(1-Extraído da monografia do primeiro autor do curso de Especialização em Meio Ambiente e Gestão Ambiental da UDESC/CAV; 2-Engenheiro Agrimensor; luiz@deinfra.sc.gov.br; 3Professor do Centro de Ciências Agroveterinárias da Universidade do Estado de Santa Catarina-UDESC. Caixa Postal 281, CEP 88520-000 Lages-SC, E-mail: becegato@cav.udesc.br; a2oaf@cav.udesc.br; 4-Professor da UNIPAR, E-mail: sideney@unipar.br; 5-Professor UTFPR, E-mail: wcpm@mail.crea-pr.org.br; 6 - Acadêmica do curso de Engenharia Florestal-UDESC-Lages, E-mail: florestalgabi_cav@yahoo.com.br).

\section{Resumo}

Este trabalho visa mostrar os problemas ambientais existentes e os gerados na execução dos serviços de reabilitação da rodovia SC-425 trecho BR 470/Otacílio Costa/ BR 282 e as ações corretivas aplicadas a cada problema ocorrido. A princípio foram identificados e diagnosticados os impactos das ações construtivas e das já existentes nas áreas de influência direta e indireta; dimensionados e avaliados, bem como aplicado aplicadas medidas mitigadoras. Por tratar-se da restauração da rodovia SC-425, trecho $\mathrm{Br}$ 470/Otacílio Costa/BR 282, em sua totalidade, os serviços, restringiram-se ao leito existente e áreas adjacentes degradadas.

Palavras-chave: Rodovia SC-425 restauração, meio ambiente.

\section{Abstract \\ ENVIRONMENT MANAGEMENT IN THE RECOVERY OF SC-425 HIGHWAY - STRETCH BR-470/OTACÍLIO COSTA-SC/BR-282}

This work seeks to show the existent and generated environmental problems in the execution of the rehabilitation services of the highway SC-425 space BR 470/Otacílio Costa / BR 282 and the corrective actions applied to each problem. At first were identified and diagnosed the

\footnotetext{
- Recebido para publicação em 05 de Dezembro de 2007; Aprovado para publicação em 23 de Abril de 2008
} 


\section{GEOAMBIENTE ON-LINE \\ Revista Eletrônica do Curso de Geografia do Campus Jataí - UFG \\ www.jatai.ufg.br/geografia \\ | Jataí-GO | N.10 | jan-jun/2008 |

impacts of the constructive actions and of the already existent ones in the areas of direct and indirect influence; dimensioned and appraised, were applied the measured litigators. For being of the restoration of the highway SC-425 space $\mathrm{Br} 470 /$ Otacílio Costa/BR 282, in its totality, the services, limited themselves to the existent bed and degraded adjacent areas.

Key-words: Highway SC-425, restoration, environment.

\section{1 - Introdução}

O solo, a fauna, a flora e águas são entes, objetos de avaliação nas ações modificadoras, sempre buscando a preservação, na medida do possível, nos trabalhos desenvolvidos nas rodovias. No particular, a reabilitação da SC 425 trecho BR 282/ Otacílio Costa/ BR 470.

Por tratar-se de uma obra de reabilitação, as intervenções construtivas limitaram-se ao leito existente, adjacências, canteiros de operações e áreas industriais. Inicialmente, foram analisados os projetos, especificações e normas referentes ao assunto procurando avaliar, na totalidade, as ocorrências impactantes e preventivas.

A gestão ambiental nas rodovias, além de manejar o ambiente com ações e atividades intencionalmente aplicadas para impedir ou atenuar manifestações indesejáveis de impactos ambientais controláveis, deve monitorar as mesmas, acompanhando as transformações geradas (FOGLIATTI et al. 2004).

A carência de infra-estrutura de transportes no país mostra a enorme demanda de um sistema viário abrangente, técnica e ambientalmente bem concebido, para compatibilizar o esforço desenvolvimentista do Governo Federal com um sistema logístico de transporte à altura do país com dimensões continentais e que necessita ser competitivo (MORALES, 2005), ou seja, é possível compatibilizar crescimento econômico com a proteção ao Meio Ambiente, desde que haja um correto tratamento ambiental. Nesta mesma linha, (DUTRA, et al. 2007), lembram que a questão ambiental não é apenas um problema ecológico, possui também uma vertente social e que a sociedade exige que se o meio ambiente foi degradado, deve ser reparado.

É importante ressaltar, entretanto, que é possível compatibilizar o processo de construção rodoviária com a conservação ambiental, desde que a boa técnica rodoviária seja incorporada nos métodos e atividades construtivas, a fim de evitar a degradação ambiental (PARANÁ, 2000). 


\section{GEOAMBIENTE ON-LINE \\ Revista Eletrônica do Curso de Geografia do Campus Jataí - UFG \\ www.jatai.ufg.br/geografia \\ | Jataí-GO | N.10 | jan-jun/2008

O tratamento ambiental consiste em buscar a adequada eliminação, mitigação ou compensação de impactos ambientais negativos, suscetíveis de ocorrer em toda a sua abrangência, como decorrência do processo construtivo e da posterior operação da via (BRASIL, 2005).

Com relação às propriedades atingidas foram avaliadas e indenizadas com valores atualizados e compatíveis. Foram descritas as ações desenvolvidas pelos órgãos rodoviários e ambientais, com aplicações das normas e regras de controle ambiental na execução do empreendimento rodoviário, desde a sua concepção, execução e operação.

O objetivo do presente trabalho foI caracterizar os impactos ambientais na restauração da rodovia SC 425 trecho BR 470/ Otacílio Costa/BR 282.

\section{2 - Metodologia}

\section{1 - Projetos de Implantação e Pavimentação}

Nos casos de projetos de Implantação e Pavimentação em função de sua maior abrangência e complexidade, bem como foram identificadas as principais tarefas a serem desenvolvidas para a elaboração de estudos e projetos. Os projetos de restauração e melhoria constituem casos especiais com menos nível de exigência nos estudos.

Os Estudos e Projetos de Meio Ambiente na fase de Pré-Análise, os conteúdos e a apresentação dos respectivos resultados estão resumidos na Tabela 1.

Tabela 1. Fases de implantação do planejamento

\begin{tabular}{|c|c|c|c|}
\hline \multirow[b]{2}{*}{ Tarefas } & \multirow[b]{2}{*}{ Conteúdo } & \multicolumn{2}{|c|}{ Apresentação } \\
\hline & & Texto & $\begin{array}{c}\text { Mapa/ } \\
\text { Matrizes etc. }\end{array}$ \\
\hline $\begin{array}{l}\text { 1. Definição dos Objetivos } \\
\text { Ambientais do Projeto }\end{array}$ & $\begin{array}{l}\text { Formular diretrizes ambientais } \\
\text { que oriente as demais fases da } \\
\text { elaboração do Projeto Final de } \\
\text { Engenharia. }\end{array}$ & $X$ & \\
\hline \begin{tabular}{|lll} 
2. & Análise de Potenciais \\
& Conflitos Sócio-Político
\end{tabular} & $\begin{array}{l}\text { Resultados dos entendimentos } \\
\text { com a sociedade civil, } \\
\text { entidades, órgãos e técnicos } \\
\text { envolvidos. }\end{array}$ & $X$ & \\
\hline $\begin{array}{l}\text { 3. Delimitação da Área de } \\
\text { Estudo }\end{array}$ & $\begin{array}{lll}\text { Delimitação } & \text { da área } & \text { de } \\
\text { influência da } & \text { rodovia } & \text { e } \\
\text { obras. }\end{array}$ & $X$ & $\begin{array}{c}\text { Mapa na escala } \\
1: 50.000\end{array}$ \\
\hline \begin{tabular}{|llll} 
4. & Caracterização & da & Área \\
Ambiental da Área & de \\
Influência & & &
\end{tabular} & $\begin{array}{l}\text { Caracterização ambiental da } \\
\text { área de influência que permita } \\
\text { definir o mapeamento das áreas }\end{array}$ & $X$ & $\begin{array}{c}\text { Mapa na escala } \\
1: 50.000\end{array}$ \\
\hline
\end{tabular}




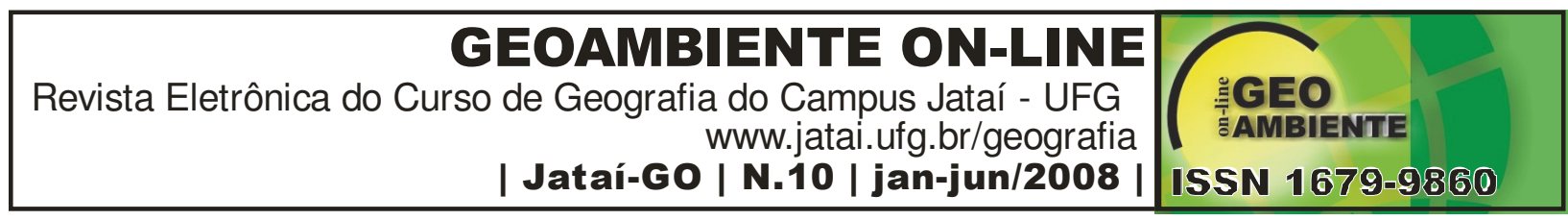

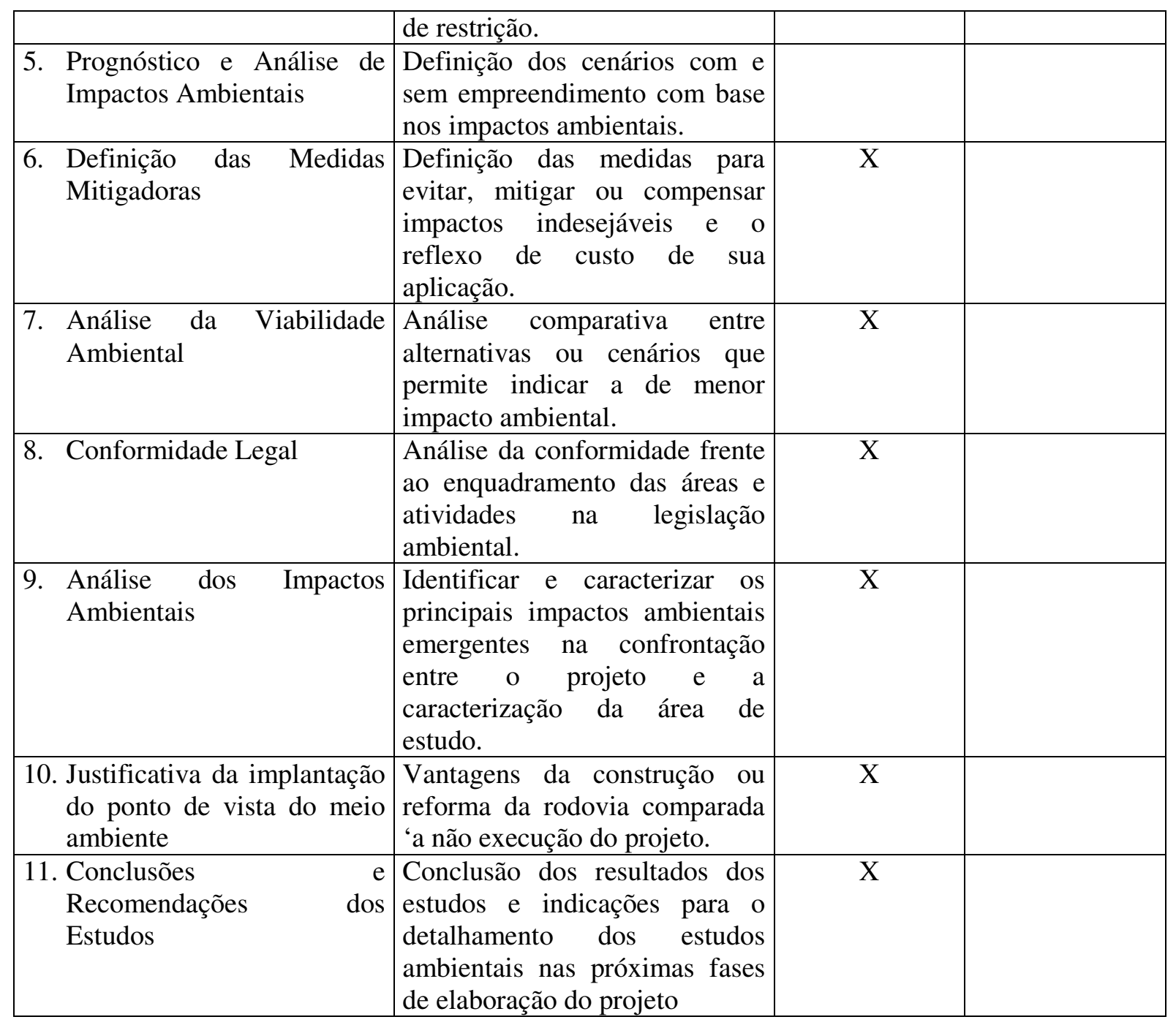

Definiram-se as medidas para evitar, mitigar ou compensar os impactos ambientais estimando-se os recursos necessários para programar as medidas propostas, classificando o volume dos recursos necessários para realizar as medidas em uma escala considerando-os como "pequeno", "médio" ou "grande", conforme apresentado na Tabela 2.

Tabela 2. Medidas para evitar, mitigar e compensar os impactos ambientais identificados

\begin{tabular}{|c|c|c|c|}
\hline $\begin{array}{c}\text { Item a } \\
\text { proteger } \\
\text { Resolução }\end{array}$ & $\begin{array}{c}\text { Impactos ambientais } \\
\text { identificados }\end{array}$ & $\begin{array}{c}\text { Medidas para evitar } \\
\text { os impactos } \\
\text { ambientais } \\
\text { exeqüíveis sim } \\
\text { (medidas) não }\end{array}$ & $\begin{array}{c}\text { Medidas mitigadoras } \\
\text { e compensatórias }\end{array}$ \\
\hline & $\begin{array}{c}\text { conflito de uso e } \\
\text { ocupação do solo; } \\
\text { alteração das condições } \\
\text { de vida da população }\end{array}$ & $\operatorname{sim}$ & $\operatorname{sim}$ \\
\hline
\end{tabular}




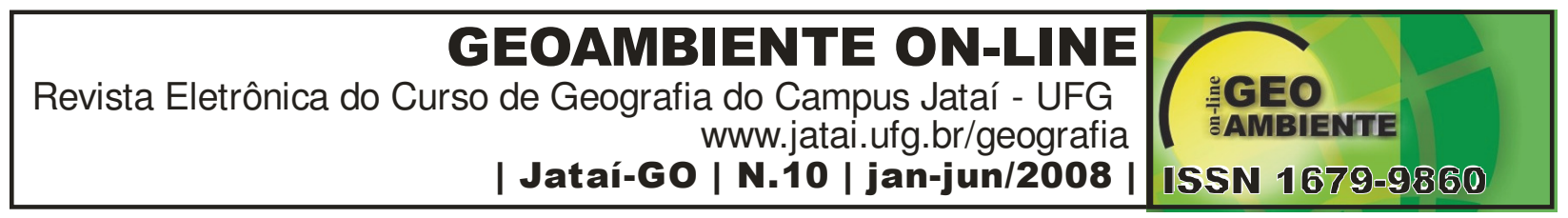

\begin{tabular}{|c|c|c|c|}
\hline $\begin{array}{l}\text { 1. A saúde, a } \\
\text { segurança e o } \\
\text { bem- estar da } \\
\text { população }\end{array}$ & $\begin{array}{l}\text { local; } \\
\text { maior segurança do } \\
\text { tráfego; } \\
\text { - danos por ruído; } \\
\text { - } \text { danos por vibrações; } \\
\text { - danos/perda de materiais } \\
\text { bens (desapropriação); } \\
\text { - } \text { segregação urbana; } \\
\text { - danos/perda de sítios/ } \\
\text { monumentos } \\
\text { arqueológicos; } \\
\text { - danos/perda } \\
\text { sítios/monumentos de } \\
\text { históricos } \\
\text { danos/perda } \\
\text { sítios/monumentos de } \\
\text { culturais; }\end{array}$ & $\begin{array}{l}\text { sim } \\
\text { sim } \\
\text { sim } \\
\text { sim } \\
\text { sim }\end{array}$ & $\begin{array}{l}\text { sim } \\
\text { sim } \\
\text { sim } \\
\text { sim } \\
\text { sim }\end{array}$ \\
\hline $\begin{array}{c}\text { 2. As } \\
\text { atividades } \\
\text { sócio- } \\
\text { econômicas }\end{array}$ & 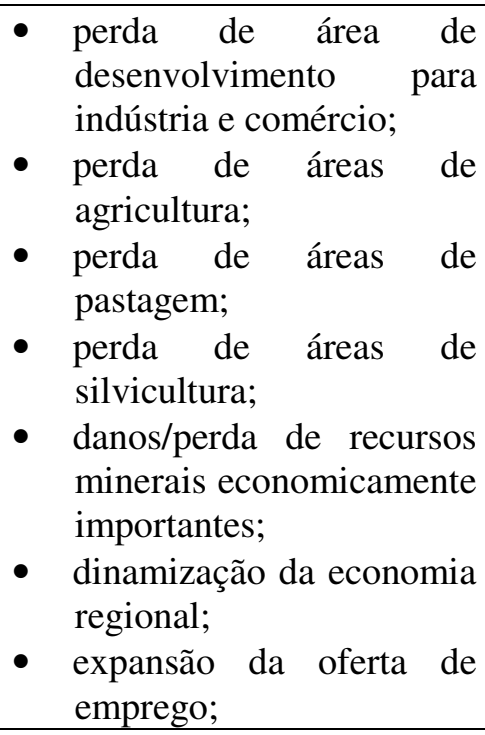 & $\begin{array}{l}\operatorname{sim} \\
\operatorname{sim} \\
\operatorname{sim} \\
\operatorname{sim}\end{array}$ & $\begin{array}{l}\text { sim } \\
\text { sim } \\
\text { sim } \\
\text { Sim }\end{array}$ \\
\hline 3.A biota & $\begin{array}{l}\text { - } \text { impedimento dos } \\
\text { processos de intercâmbio } \\
\text { ecológicos por corte de } \\
\text { áreas; } \\
\text { - danos às áreas protegidas; } \\
\text { - danos aos biótopos } \\
\text { ecológicos importantes; } \\
\text { - perda/corte de florestas } \\
\text { primárias; } \\
\text { - perda/corte de capoeirões; } \\
\text { - perda/corte de capoeiras; } \\
\text { - perda/corte de } \\
\text { capoeirinhas; } \\
\text { pressão } \\
\text { ecossistemas terrestres e } \\
\text { aquáticos; }\end{array}$ & $\begin{array}{l}\text { sim } \\
\text { sim } \\
\text { sim } \\
\text { sim } \\
\text { sim } \\
\operatorname{sim}\end{array}$ & $\begin{array}{l}\text { sim } \\
\text { sim } \\
\text { sim } \\
\text { sim } \\
\text { sim } \\
\text { sim }\end{array}$ \\
\hline
\end{tabular}




\section{GEOAMBIENTE ON-LINE}

Revista Eletrônica do Curso de Geografia do Campus Jataí - UFG

\begin{tabular}{|c|c|c|c|}
\hline $\begin{array}{c}\text { 4. As } \\
\text { condições } \\
\text { estéticas do } \\
\text { meio } \\
\text { ambiente }\end{array}$ & $\begin{array}{l}\text { - } \text { danos à imagem da } \\
\text { paisagem; } \\
\text { - danos às relações de } \\
\text { visibilidade; } \\
\text { - outros... }\end{array}$ & $\operatorname{sim}$ & $\operatorname{sim}$ \\
\hline $\begin{array}{c}\text { 5. A } \\
\text { qualidade } \\
\text { dos recursos } \\
\text { naturais }\end{array}$ & $\begin{array}{ll}\text { - } & \text { Solo; } \\
\text { - } & \text { retirada de solos; } \\
\text { - } & \text { erosão; } \\
\text { - } & \text { alteração da estrutura } \\
& \text { de solos; } \\
\text { - } & \text { danos por concentração } \\
& \text { de poluentes; } \\
\text { - } & \text { água; } \\
\text { - } & \text { rebaixamento do lençol } \\
& \text { freático; } \\
\text { - } & \text { influências sobre a } \\
& \text { qualidade de água } \\
& \text { subterrânea } \\
& \text { concentração } \\
& \text { poluentes; } \\
\text { - } & \text { corta-rios; } \\
\text { - } & \text { alteração da qualidade } \\
& \text { de água superficial por } \\
& \text { concentração } \\
& \text { poluentes; } \\
& \text { do alteração da qualimarartes); } \\
& \\
\text { impento dos processos de }\end{array}$ & $\begin{array}{l}\operatorname{sim} \\
\operatorname{sim} \\
\operatorname{sim} \\
\operatorname{sim} \\
\operatorname{sim} \\
\operatorname{sim} \\
\operatorname{sim}\end{array}$ & $\begin{array}{l}\text { sim } \\
\operatorname{sim} \\
\operatorname{sim} \\
\operatorname{sim} \\
\operatorname{sim} \\
\operatorname{sim} \\
\operatorname{sim}\end{array}$ \\
\hline
\end{tabular}




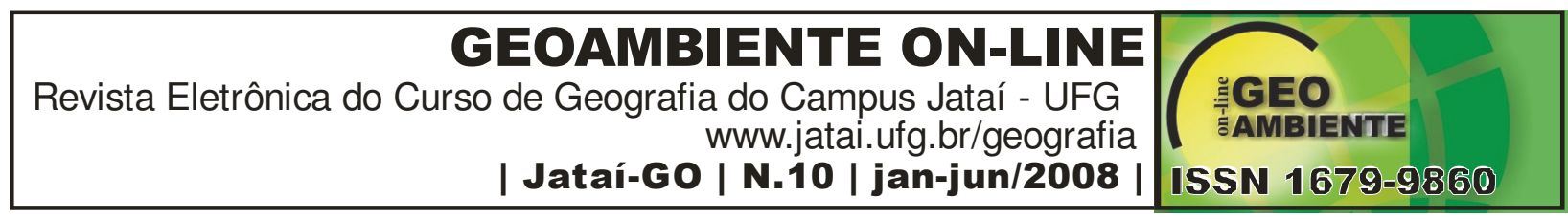

\begin{tabular}{|l|l|c|c|}
\hline intercâmbio de ar; & $\operatorname{sim}$ & $\operatorname{sim}$ \\
\hline
\end{tabular}

\section{2 - Projeto ambiental}

O Projeto Ambiental consistiu de documento que consolida as medidas preventivas e mitigadoras de impactos ambientais indesejáveis, previstos nos estudos realizados ao longo de toda a elaboração do projeto desde a fase de pré-análise, inclusive no EIA e RIMA, quando solicitado:

- $\mathrm{O}$ atendimento das condicionantes ambientais previstas na legislação e nas normas vigentes, necessários para a obtenção da LAI; e

- A indicação dos procedimentos, especificações técnicas e dispositivos necessários à implementação das medidas de proteções a serem adotadas na fase de obras para cada modalidade de impactos ambiental indesejável.

O Projeto Ambiental deve apresentar o detalhamento dos dispositivos de proteção ambiental e as especificações técnicas aplicáveis, quantificando-se os materiais necessários para implementação tendo como componentes obrigatórios, desde que não contidos em itens específicos no Projeto Final de Engenharia, os seguintes tópicos:

- Supressão de vegetação;

- Contenção de sedimentos e mitigação de processos erosivos;

- Segurança de pedestres;

- Disposição de resíduos gerados nas obras (bota fora);

- Paisagismo;

- Projetos de Recuperação Ambiental de Áreas de Apoio;

- Recuperação de Passivos Ambientais;

- Obras Complementares; e

- Áreas de Apoio.

\section{3 - Fase de projeto executivo}

O objetivo dos trabalhos na fase de Projeto Final de Engenharia é o detalhamento dos impactos ambientais e das medidas mitigadoras ou compensatórias para a alternativa escolhida, elaboração dos documentos técnicos do projeto de meio ambiente e do relatório 


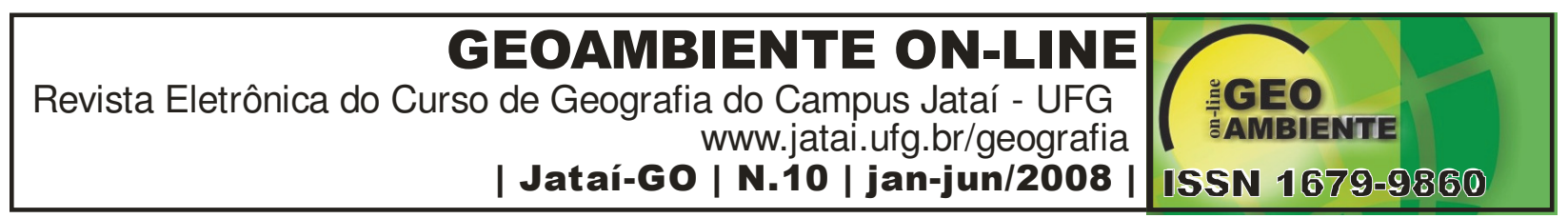

denominado estudos ambientais, que deverão ser suficientes para orientar a elaboração do edital de licitação correspondente e do respectivo contrato de prestação de serviços (obras).

\section{4 - Projeto de execução das obras rodoviárias}

Os projetos construtivos com relevância ambiental sejam para execução de projetos de engenharia, seja para a execução da obra, devem ser detalhados para garantir uma execução adequada. Além disso, estes projetos devem ser realizados sob a observação dos "regulamentos" existentes.

Os "regulamentos" a serem considerados constam no Manual de Procedimentos Ambientais e Diretrizes Ambientais do DEINFRA (2003) e, na ausência de dispositivos regulamentares, deverão ser considerados os do DNIT (denominação atual do DNER), constantes no Corpo normativo Ambiental para Empreendimentos Rodoviários, nas Instruções de Proteção Ambiental das faixas de domínio e lindeiras das Rodovias Federais, no Manual Rodoviário de Conservação, Monitoramento e Controle Ambiental e Manual para Ordenamento do Uso do Solo nas Faixas de Domínio e Lindeiras das Rodovias Federal, entre outros.

\section{5 - Revestimento vegetal}

O projeto paisagístico deve considerar as seguintes recomendações da caracterização e dimensionamento da cobertura vegetal:

- Percepção de interseções em tempo oportuno;

- Melhoria da condição ótica;

- Influência da velocidade de trafego em áreas com risco de acidentes;

- Proteção contra erosão e deslizamentos;

- Configuração para configurar a monotonia da paisagem;

- Proteção contra emissões causadas pelo trafego;

- Proteção ótica de áreas habitacionais e de lazer;

- Integração paisagística de cortes e aterros;

- Integração paisagística de obras de arte especiais (O.A.E.); 


\section{GEOAMBIENTE ON-LINE \\ Revista Eletrônica do Curso de Geografia do Campus Jataí - UFG www.jatai.ufg.br/geografia \\ | Jataí-GO \\ | N.10 | jan-jun/2008

- Medidas de configuração em áreas florestais (configuração de margens de florestas, plantio de proteção contra vento lateral em entradas e saídas de florestas);

- Revegetação de áreas devastadas (área de trabalho, jazidas, pedreiras, etc.);

\section{3 - Resultados e Discussão}

\section{1 - Passivos Ambientais}

Selecionou-se 72 passivos ambientais (Tabela 3), bem como documentação complementando com o registro fotográfico (pequena amostra), destacando a situação de diversos passivos ambientais antes e depois da recuperação (Figuras 1, 2, 3, 4, 5 e 6). Na Tabela 4 um diagrama de localização dos passivos, um quadro indicando o grau de risco de cada passivo, uma planilha com as características físicas das obras.

Tabela 3. Grau de risco de um Passivo Ambiental (IS-5/04).

\begin{tabular}{|l|c|c|c|c|c|l|}
\hline \multicolumn{1}{|c|}{ Localização } & Lado & $\mathbf{N}^{\mathbf{0}}$ & Tipo & Gravidade & \multicolumn{1}{|c|}{ Solução } & \multicolumn{1}{|c|}{ Observações } \\
\hline $88+450$ ao PF & DE & 01 & OU & CR & $\begin{array}{l}\text { Ambiental e } \\
\text { Fiscalização }\end{array}$ & $\begin{array}{l}\text { Interseção e Poluição } \\
\text { Visual }\end{array}$ \\
\hline $88+300$ a $88+420$ & D & 02 & TE & CR & $\begin{array}{l}\text { Fiscalização } \\
\text { e Engenharia }\end{array}$ & $\begin{array}{l}\text { Acesso ao } \\
\text { Estacionamento de bar e } \\
\text { restaurante. }\end{array}$ \\
\hline $88+120$ a $88+320$ & D & 03 & OU & CR & $\begin{array}{l}\text { Fiscalização } \\
\text { e Engenharia }\end{array}$ & $\begin{array}{l}\text { Áreas de lazer e tanques } \\
\text { piscicultura. }\end{array}$ \\
\hline $84+580$ a $84+730$ & E & 04 & CO & PCR & Engenharia & Erosão Corte \\
\hline $84+570$ a $84+640$ & D & 05 & CO & SR & Engenharia & Erosão Corte \\
\hline $83+920$ a $84+060$ & D & 06 & CO & SR & Engenharia & \\
\hline $83+500$ a $83+720$ & D & 07 & OU & CR & $\begin{array}{l}\text { Fiscalização } \\
\text { e Engenharia }\end{array}$ & Açude próximo a via \\
\hline $83+600$ a $83+700$ & E & 08 & CE & S R & Ambiental & $\begin{array}{l}\text { Erosão em caixa } \\
\text { empréstimo }\end{array}$ \\
\hline $79+740$ a $80+020$ & DE & 09 & OU & C R & Ambiental & Árvores próximas a via \\
\hline $79+360$ & DE & 10 & OU & CR & Engenharia & $\begin{array}{l}\text { Ponte guarda corpo } \\
\text { quebrado }\end{array}$ \\
\hline $78+960$ a $79+100$ & E & 11 & CO & SR & Engenharia & Erosão Corte \\
\hline $77+700$ a $77+800$ & E & 12 & CO & PCR & Engenharia & Erosão Corte \\
\hline $75+500$ a $76+640$ & D & 13 & AT & CR & Engenharia & Erosão Corte \\
\hline $74+850$ a $74+970$ & E & 14 & CO & CR & Engenharia & Escorregamento Corte \\
\hline $72+820$ a $72+900$ & E & 15 & AT & SR & Engenharia & Erosão Aterro \\
\hline $72+700$ a $78+780$ & E & 16 & CO & SR & Engenharia & Erosão Corte \\
\hline $72+200$ a $72+340$ & D & 17 & OU & CR & Engenharia & Açude próximo. Via \\
\hline
\end{tabular}


GEOAMBIENTE ON-LINE

Revista Eletrônica do Curso de Geografia do Campus Jataí - UFG www.jatai.ufg.br/geografia

| Jataí-GO | N.10 | jan-jun/2008

¿GEO

AMBIENTE

ISSN 1679-9860

\begin{tabular}{|c|c|c|c|c|c|c|}
\hline $72+200$ & $\mathrm{DE}$ & 18 & $\mathrm{OU}$ & $\mathrm{CR}$ & Engenharia & Ponte guarda corpo \\
\hline $71+950^{\mathrm{a}} 72+080$ & $\mathrm{E}$ & 19 & $\mathrm{CO}$ & PC R & Engenharia & Erosão Corte \\
\hline $71+700^{\mathrm{a}} 71+800$ & $\mathrm{E}$ & 20 & AT & SR & Engenharia & $\begin{array}{l}\text { Erosão acostamento e } \\
\text { aterro }\end{array}$ \\
\hline $71+150$ & $\mathrm{E}$ & 21 & $\mathrm{OU}$ & PCR & Engenharia & Erosão acesso séc. \\
\hline $71+100^{\mathrm{a}} 71+240$ & $\mathrm{E}$ & 22 & $\mathrm{CO}$ & SR & Engenharia & Erosão corte \\
\hline $65+840$ & $\mathrm{DE}$ & 23 & $\mathrm{OU}$ & $\overline{\mathrm{CR}}$ & $\begin{array}{l}\begin{array}{l}\text { Engenharia e } \\
\text { Ambiental }\end{array} \\
\end{array}$ & $\begin{array}{l}\text { Ponte se defesas -ETA } \\
\text { da CASAN }\end{array}$ \\
\hline $65+730$ a $65+780$ & $\mathrm{E}$ & 24 & TE & SR & Engenharia & $\begin{array}{l}\text { Erosão Corte ETA } \\
\text { CASAN }\end{array}$ \\
\hline $65+600 \mathrm{a} 65+700$ & $\mathrm{D}$ & 25 & $\mathrm{CO}$ & PCR & Engenharia & Erosão Corte \\
\hline $64+640^{\mathrm{a}} 64+780$ & $\mathrm{E}$ & 26 & $\mathrm{CO}$ & PCR & Engenharia & Erosão Valetão Lateral \\
\hline $65+700^{\mathrm{a}} 65+700$ & $\mathrm{DE}$ & $26-\mathrm{a}$ & NU & $\mathrm{CR}$ & Engenharia & $\begin{array}{l}\text { Passagem urbana de } \\
\text { palmeiras }\end{array}$ \\
\hline $64+000$ & $\mathrm{DE}$ & 27 & $\mathrm{OU}$ & $\mathrm{CR}$ & Engenharia & $\begin{array}{l}\text { Ponte guarda corpo } \\
\text { quebrado }\end{array}$ \\
\hline $63+920$ & $\mathrm{E}$ & 28 & OU & PCR & $\begin{array}{l}\text { Engenharia } \\
\text { Fiscalização }\end{array}$ & $\begin{array}{l}\text { Erosão na barragem } \\
\text { açude }\end{array}$ \\
\hline $63+780^{\mathrm{a}} 63+900$ & $\mathrm{DE}$ & 29 & $\mathrm{CO}$ & PCR & engenharia & Erosão Corte \\
\hline $63+780$ & $\mathrm{E}$ & 30 & $\mathrm{OU}$ & PC R & \begin{tabular}{|l|} 
Engenharia \\
Fiscalização \\
\end{tabular} & $\begin{array}{l}\text { Erosão na barragem } \\
\text { açude }\end{array}$ \\
\hline $63+300$ a $63+500$ & $\mathrm{DE}$ & $\begin{array}{c}31 \mathrm{e} \\
32\end{array}$ & $\mathrm{CO}$ & PCR & Engenharia & Erosão corte \\
\hline $62+970$ a $63+140$ & $\mathrm{D}$ & 33 & $\mathrm{CE}$ & PCR & $\begin{array}{l}\text { Engenharia } \\
\text { Fiscalização }\end{array}$ & $\begin{array}{l}\text { Erosão em caixa } \\
\text { empréstimo }\end{array}$ \\
\hline $62+980$ a $63+040$ & $\mathrm{E}$ & 34 & TE & SR & $\begin{array}{l}\text { Ambiental e } \\
\text { Fiscalização }\end{array}$ & $\begin{array}{l}\text { Entulho na faixa de } \\
\text { domínio }\end{array}$ \\
\hline $62+520$ a $62+620$ & $\mathrm{E}$ & 35 & $\mathrm{CO}$ & PCR & Engenharia & Erosão Corte \\
\hline $61+740$ a $61+760$ & $\mathrm{D}$ & 36 & $\mathrm{CO}$ & $\mathrm{CR}$ & Engenharia & Erosão Corte \\
\hline $58+150$ a $58+280$ & $\mathrm{D}$ & 37 & TE & CR & $\begin{array}{l}\text { Engenharia } \\
\text { Fiscalização } \\
\end{array}$ & Exploração indevida \\
\hline $58+120$ a $58+180$ & $\mathrm{E}$ & 38 & $\mathrm{CO}$ & SR & Engenharia & Erosão Corte \\
\hline $58+000$ a $58+080$ & $\mathrm{E}$ & 39 & $\mathrm{CO}$ & SR & Engenharia & Erosão Corte \\
\hline $58+000$ a $58+180$ & $\mathrm{D}$ & 40 & TE & SR & Engenharia & Exploração indevida \\
\hline $57+120$ & $\mathrm{DE}$ & 41 & OU & CR & Engenharia & $\begin{array}{l}\text { Ponte guarda corpo } \\
\text { quebrado }\end{array}$ \\
\hline $55+850$ a $55+980$ & $\mathrm{D}$ & 42 & $\mathrm{CO}$ & SR & Engenharia & Erosão corte \\
\hline $55+900$ a $55+980$ & $\mathrm{E}$ & 43 & $\mathrm{CO}$ & SR & Engenharia & Erosão corte \\
\hline $55+640$ a $55+800$ & $\mathrm{E}$ & 44 & TE & PCR & \begin{tabular}{|l|} 
Engenharia \\
Fiscalização \\
\end{tabular} & Exploração indevida \\
\hline $55+660$ a $55+740$ & $\mathrm{D}$ & 45 & $\mathrm{CO}$ & SR & Engenharia & Erosão Corte \\
\hline $55+500$ a $55+689$ & $\mathrm{E}$ & 46 & TE & PCR & $\begin{array}{l}\text { Engenharia } \\
\text { Fiscalização }\end{array}$ & Exploração indevida \\
\hline $52+700$ a $57+800$ & $\mathrm{DE}$ & 47 & NU & CR & Engenharia & $\begin{array}{l}\text { Área Urbana de Otacílio } \\
\text { Costa }\end{array}$ \\
\hline $55+420$ a $55+500$ & $\mathrm{E}$ & 48 & TE & PCR & $\begin{array}{l}\text { Engenharia } \\
\text { Fiscalização }\end{array}$ & Exploração indevida \\
\hline $55+280$ a $55+420$ & $\mathrm{E}$ & 49 & AT & $\mathrm{CR}$ & Engenharia & Voçorocas aterro \\
\hline $54+650$ a $54+660$ & $\mathrm{E}$ & 50 & TE & $\mathrm{CR}$ & $\begin{array}{l}\text { Engenharia } \\
\text { Fiscalização }\end{array}$ & Aterro na faixa \\
\hline $54+460$ a $54+580$ & $\mathrm{D}$ & 51 & TE & CR & Engenharia & Escavação na faixa \\
\hline
\end{tabular}




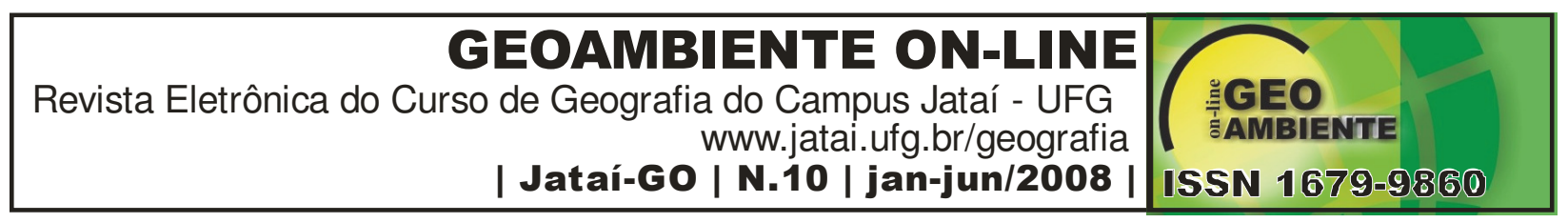

\begin{tabular}{|c|c|c|c|c|c|c|}
\hline & & & & & Fiscalização & \\
\hline $54+340$ a $54+460$ & $\mathrm{D}$ & 52 & TE & $\overline{\mathrm{CR}}$ & $\begin{array}{l}\text { Engenharia } \\
\text { Fiscalização }\end{array}$ & Aterro na faixa \\
\hline $52+480$ a $52+680$ & $\mathrm{E}$ & 53 & TE & SR & $\begin{array}{l}\text { Engenharia } \\
\text { Fiscalização }\end{array}$ & Escavação na faixa \\
\hline $52+400$ a $52+680$ & $\mathrm{D}$ & 54 & TE & $\mathrm{CR}$ & $\begin{array}{l}\text { Engenharia } \\
\text { Fiscalização }\end{array}$ & $\begin{array}{l}\text { Escavação na faixa e } \\
\text { acesso inseguro }\end{array}$ \\
\hline $51+100$ & $\mathrm{DE}$ & 55 & $\mathrm{OU}$ & $\mathrm{CR}$ & Engenharia & Ponte sem defesas \\
\hline $50+420$ a $50+520$ & $\mathrm{DE}$ & 56 & $\mathrm{CE}$ & SR & Ambiental & Erosão \\
\hline $47+040$ & $\mathrm{D}$ & 57 & AT & SR & Engenharia & Erosão Aterro \\
\hline $45+680$ & $\mathrm{D}$ & 58 & OU & $\overline{\mathrm{CR}}$ & Engenharia & $\begin{array}{l}\text { Escola sem sinalização } \\
\text { na via }\end{array}$ \\
\hline $44+900$ a $45+000$ & $\mathrm{D}$ & 59 & $\mathrm{CO}$ & PCR & $\begin{array}{l}\text { Engenharia e } \\
\text { Ambiental }\end{array}$ & $\begin{array}{l}\text { Erosão corte caminho } \\
\text { serviço }\end{array}$ \\
\hline $44+420$ a $44+460$ & $\mathrm{D}$ & 60 & TE & $\overline{C R}$ & $\begin{array}{l}\text { Engenharia } \\
\text { Fiscalização }\end{array}$ & Escavação na faixa \\
\hline $44+240$ & $\mathrm{D}$ & 61 & TE & CR & $\begin{array}{l}\text { Ambiental e } \\
\text { Fiscalização }\end{array}$ & $\begin{array}{l}\text { Depósito calcário na } \\
\text { faixa de domínio }\end{array}$ \\
\hline $43+700$ a $43+820$ & $\mathrm{E}$ & 62 & $\mathrm{CO}$ & PCR & $\begin{array}{l}\text { Engenharia } \\
\text { Fiscalizacão }\end{array}$ & Erosão corte \\
\hline $42+540$ & $\mathrm{E}$ & 63 & $\mathrm{CO}$ & PCR & Engenharia & Erosão corte \\
\hline $39+600$ & $\mathrm{DE}$ & 64 & OU & $\mathrm{CR}$ & Engenharia & $\begin{array}{l}\text { Ponte guarda corpo } \\
\text { quebrado }\end{array}$ \\
\hline $38+700$ & $\mathrm{E}$ & 65 & OU & $\overline{\mathrm{CR}}$ & $\begin{array}{l}\text { Ambiental e } \\
\text { Engenharia }\end{array}$ & Água parada \\
\hline $36+260$ a $36+380$ & $\mathrm{DE}$ & $\begin{array}{c}66 \mathrm{e} \\
67\end{array}$ & CE & PCR & $\begin{array}{l}\text { Ambiental } \\
\text { Engenharia }\end{array}$ & Erosão \\
\hline $35+820$ a $36+040$ & $\mathrm{E}$ & 68 & $\mathrm{CO}$ & PCR & Engenharia & Erosão \\
\hline $35+780$ & $\mathrm{E}$ & 69 & TE & $\mathrm{CR}$ & $\begin{array}{l}\text { Engenharia } \\
\text { Fiscalização }\end{array}$ & $\begin{array}{l}\text { Terraplanagem para } \\
\text { acesso comércio } \\
\text { informal }\end{array}$ \\
\hline $35+260$ & $\mathrm{E}$ & 70 & $\mathrm{CO}$ & PCR & Engenharia & Erosão corte \\
\hline $33+250-\mathrm{PF}$ & $\overline{\mathrm{DE}}$ & 71 & TE & $\mathrm{CR}$ & $\begin{array}{l}\text { Ambiental e } \\
\text { Fiscalização }\end{array}$ & $\begin{array}{l}\text { Comércio informal, } \\
\text { borracharia e casa }\end{array}$ \\
\hline $33+250-\mathrm{PF}$ & $\mathrm{DE}$ & 72 & OU & CR & Engenharia & $\begin{array}{l}\text { Interseção perigosa BR } \\
470\end{array}$ \\
\hline
\end{tabular}




\begin{tabular}{|c|c|}
\hline GEOAMBIENTE ON-LINE & \\
Revista Eletrônica do Curso de Geografia do Campus Jataí - UFG & www.jatai.ufg.br/geografia \\
| Jataí-Go | N.10 | jan-jun/2008 | & ISSN 1679-9860 \\
\hline
\end{tabular}

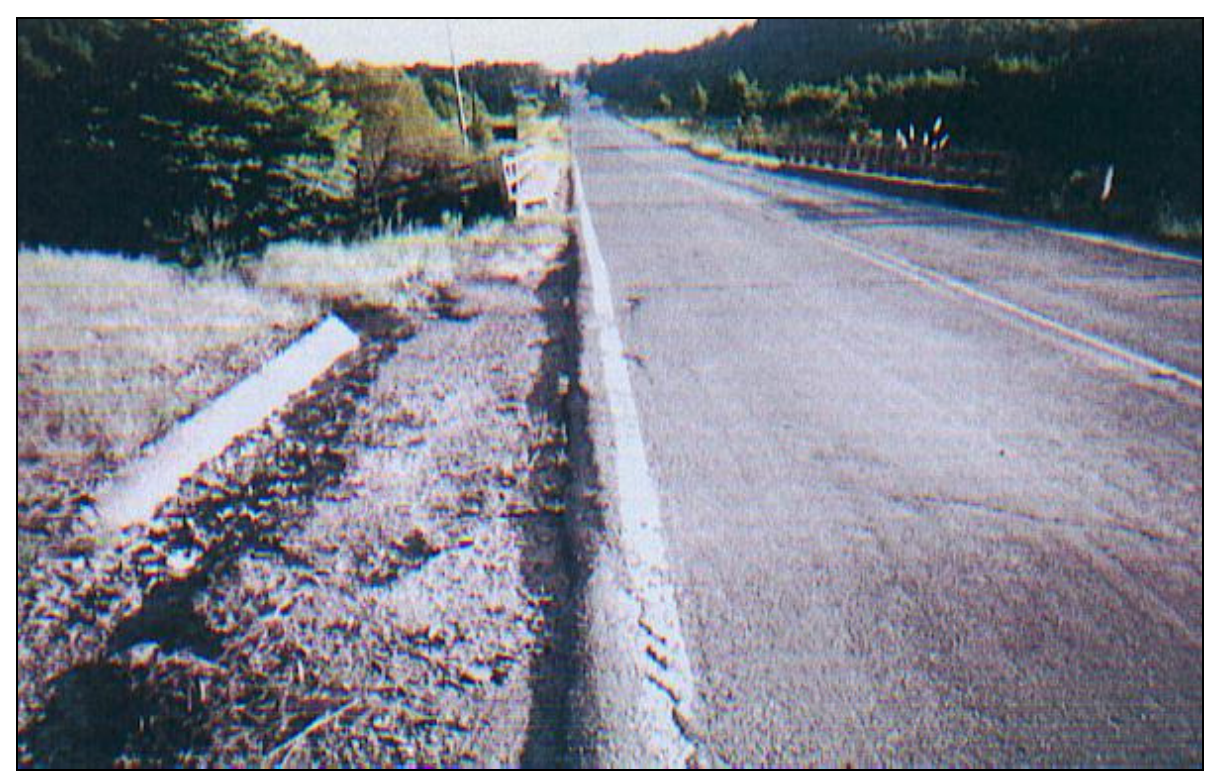

Figura 1. Detalhe da ponte sem defensa, dispositivo de drenagem destruído e sinalização precária (antes)

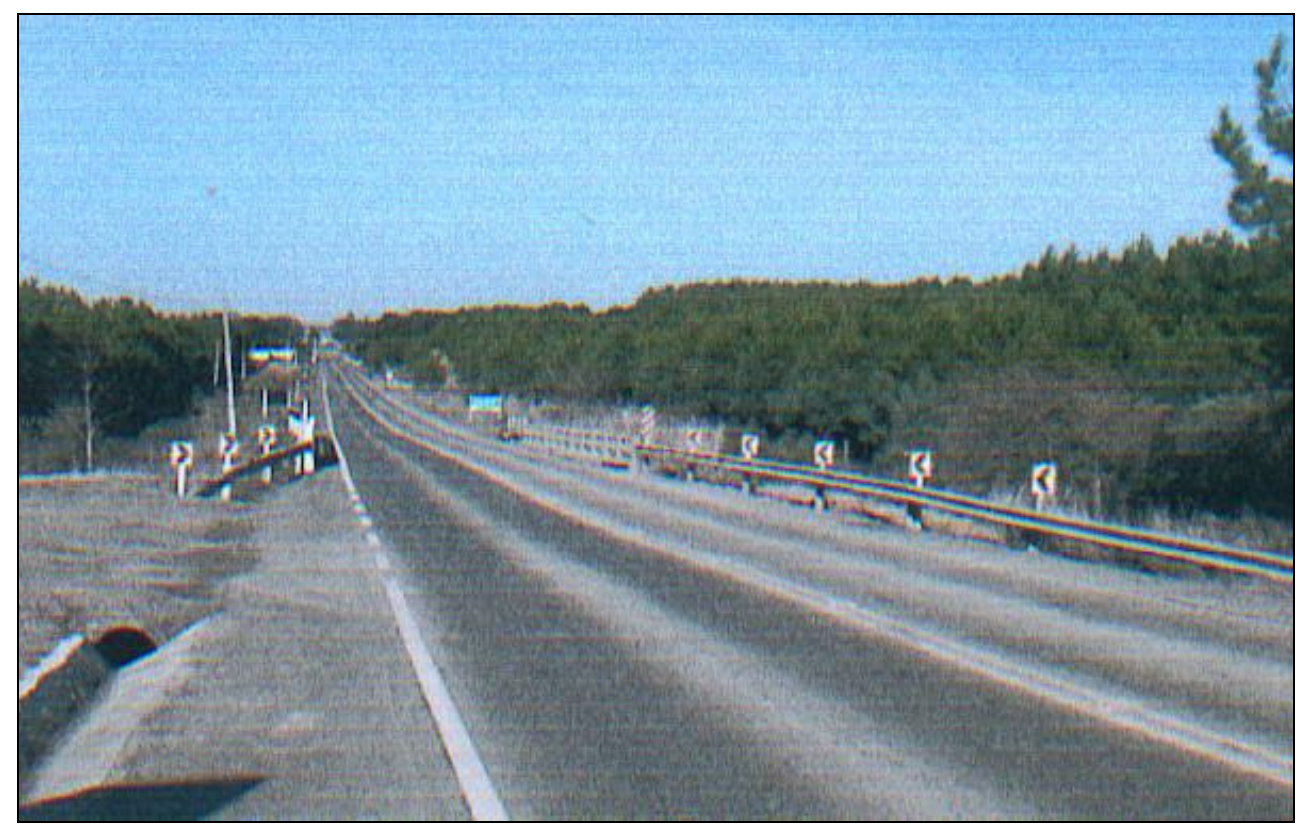

Figura 2. Detalhe dos guarda corpo reconstruídos, defensas, sarjetas, travessia de acesso secundário e sinalização executados (depois). 


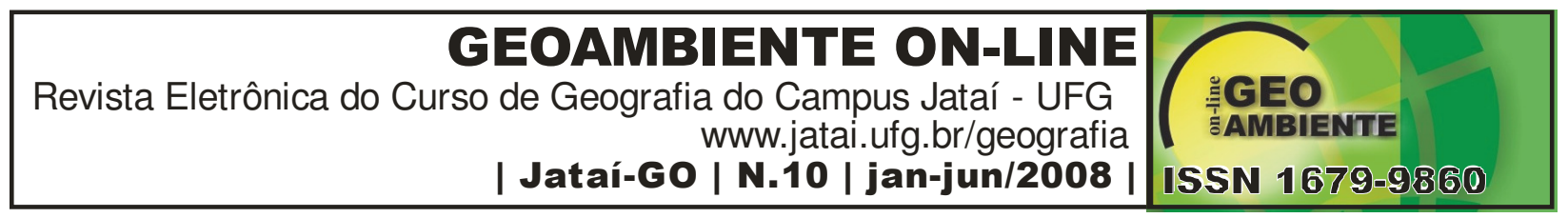

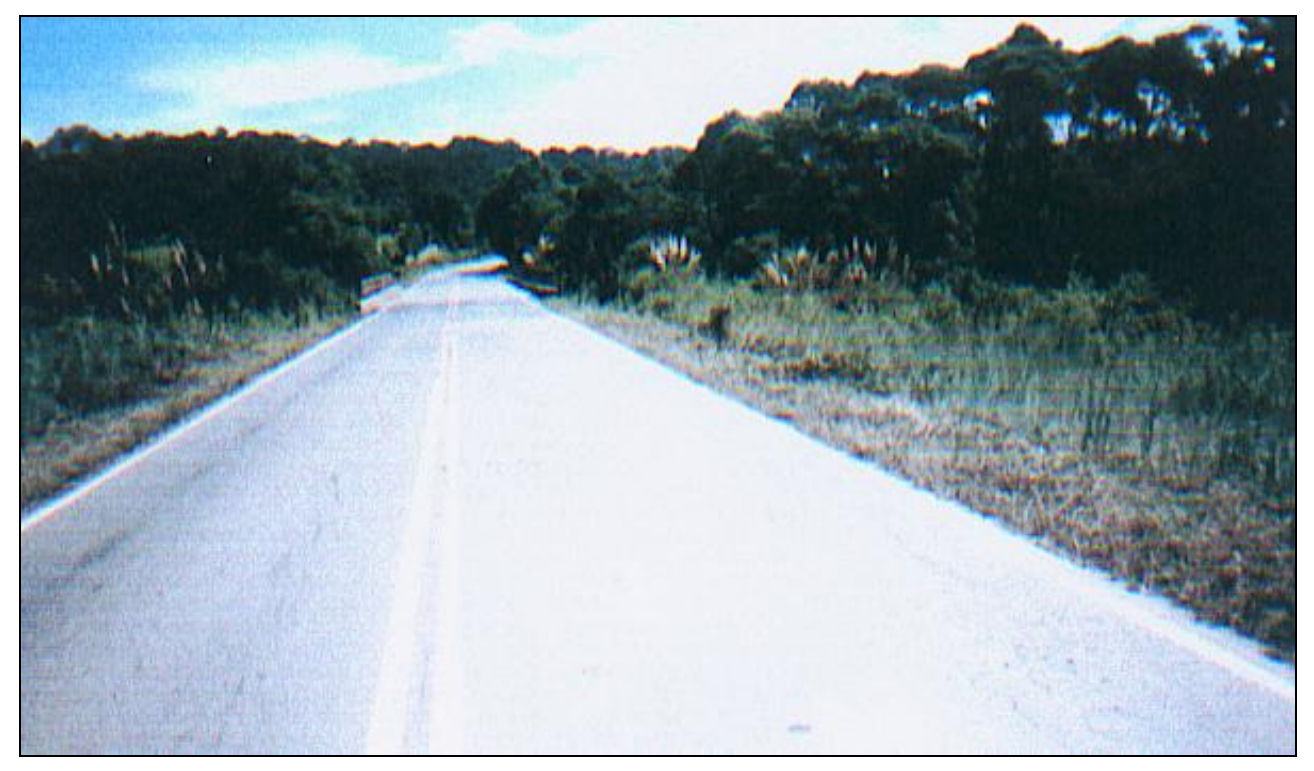

Figura 3. Ponte sem defensa e com guarda corpo e sinalização deficitária (antes)

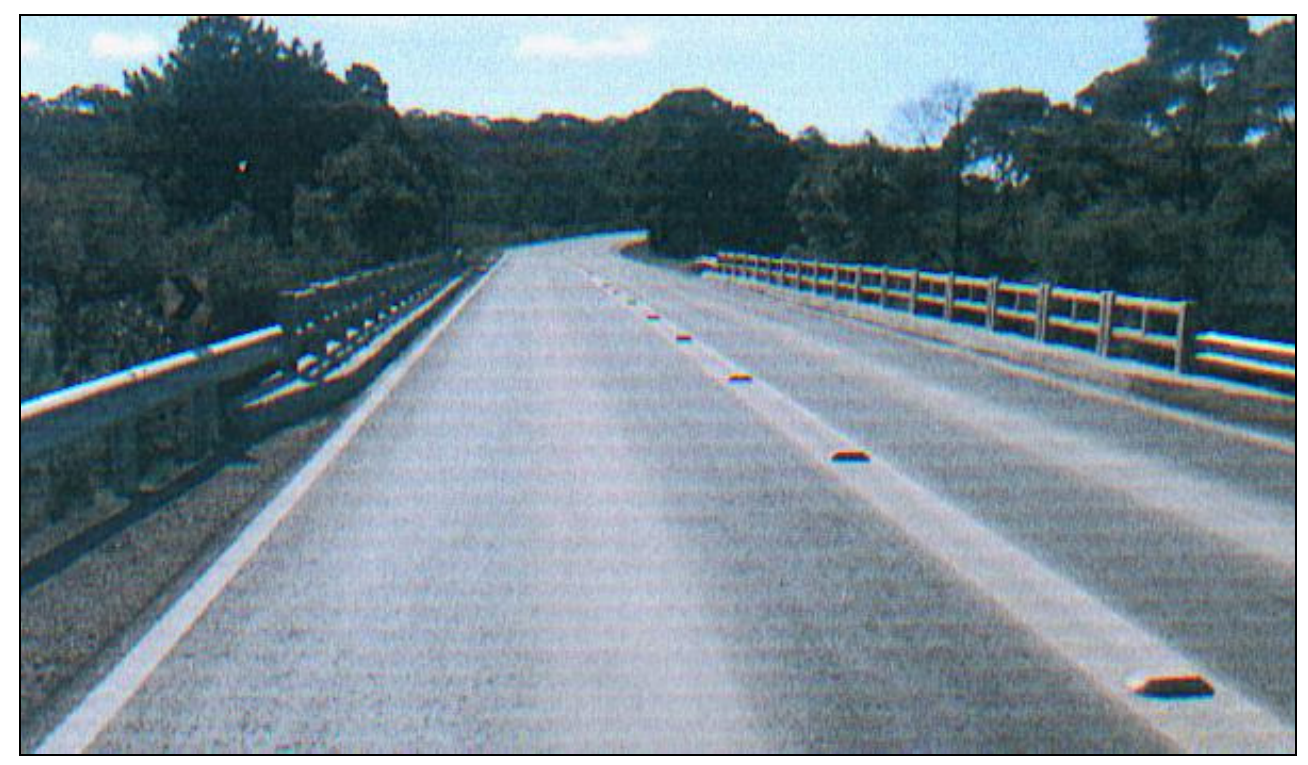

Figura 4. Detalhe da ponte com guarda corpo reconstruído, com defensas e sinalização executado (depois). 


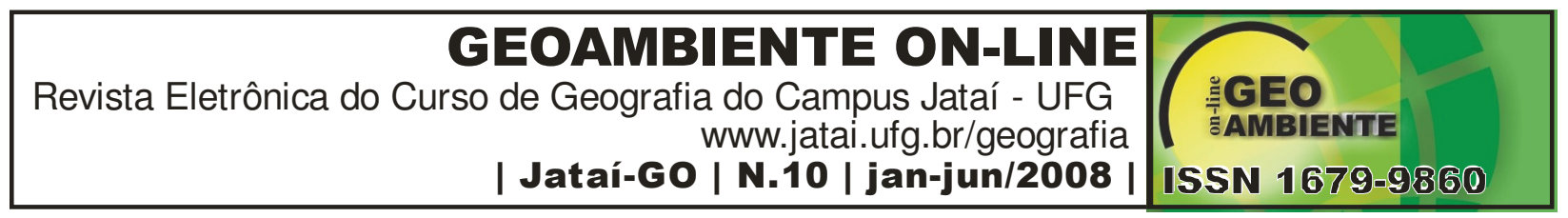

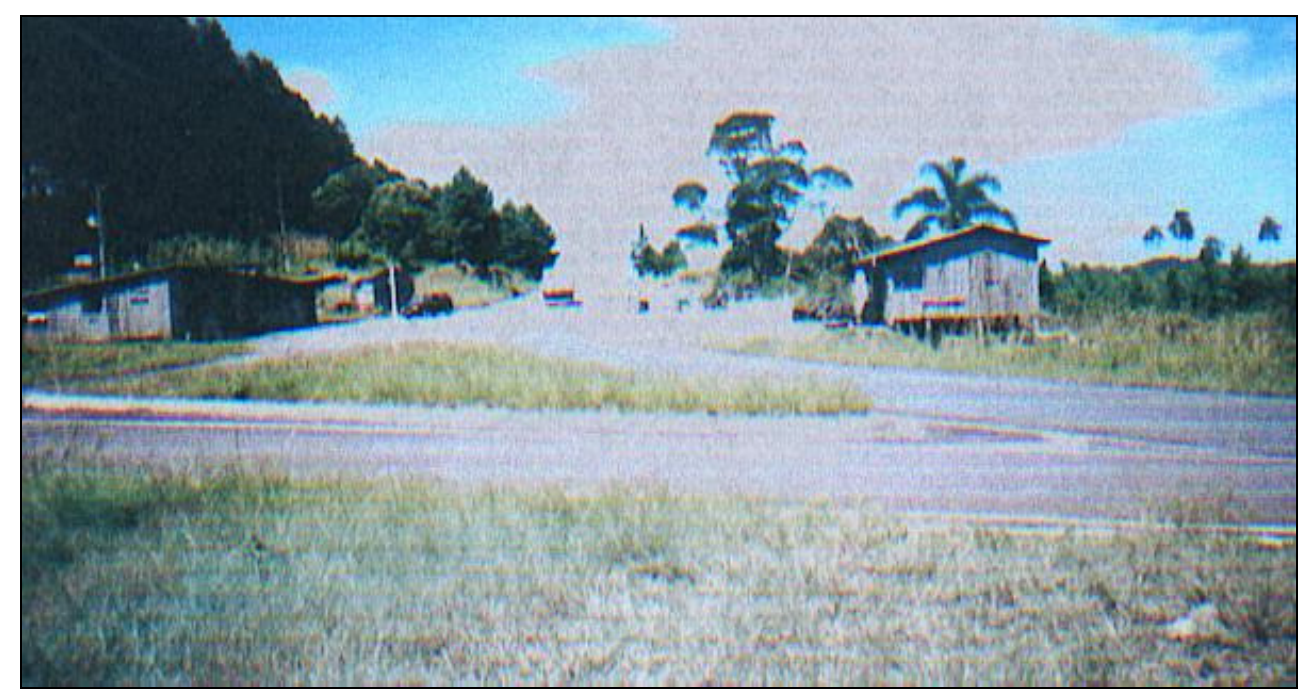

Figura 5. Detalhe da invasão de faixa de domínio por borracharias e trevo sem iluminação (antes).

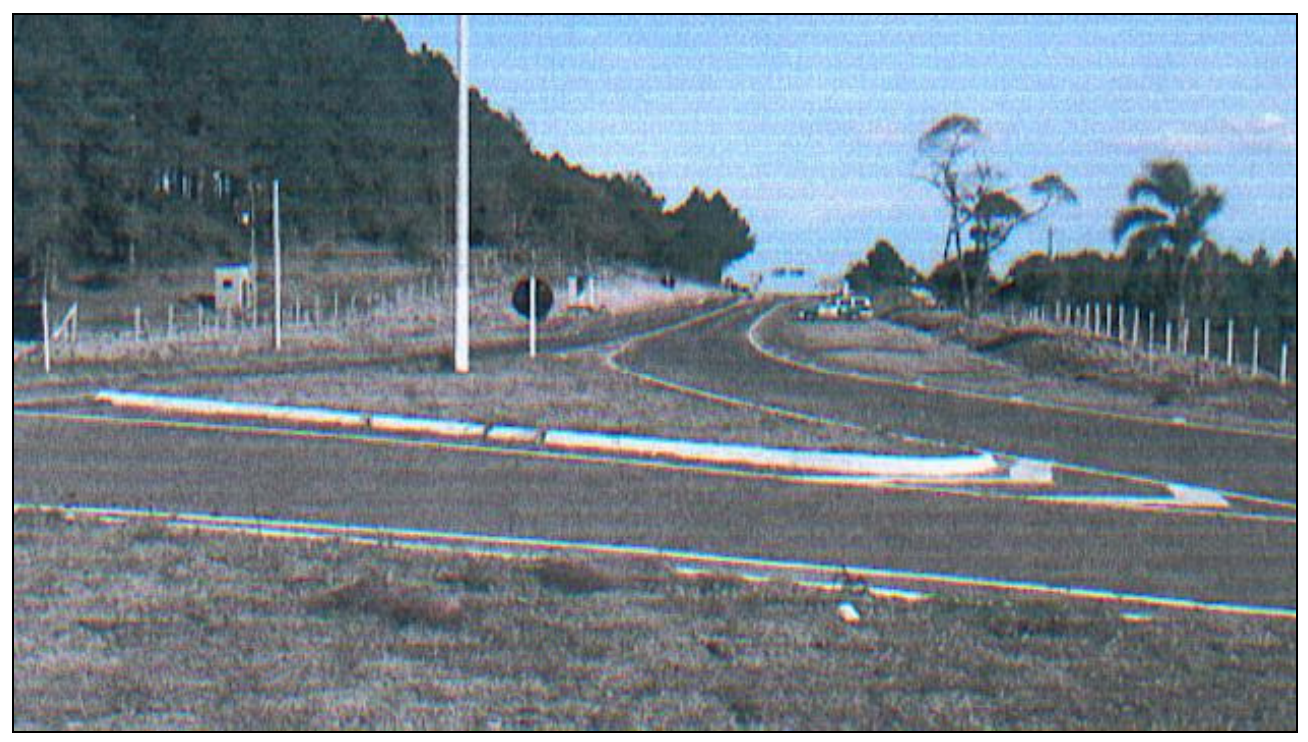

Figura 6. Execução de cercas, valas de drenagem laterais, iluminação do trevo, abrigo de ônibus, plantio de árvores e arbustos, sinalização horizontal/vertical e enleivamento nos canteiros (depois).

\section{2 - Relação de Passivos Ambientais}

Os passivos ambientais foram identificados e agrupados em:

- Núcleos Urbanos - NU

- Ações de Terceiros - TE 


\section{GEOAMBIENTE ON-LINE \\ Revista Eletrônica do Curso de Geografia do Campus Jataí - UFG www.jatai.ufg.br/geografia \\ | Jataí-GO | N.10 | jan-jun/2008

- Cortes - CO

- Aterros - AT

- Caixa de Empréstimo - CE

- Jazidas - JA

- Bota-Foras - BF

- Outros - OU

Para cada passivo fez-se uma análise quanto a gravidade e classificou-se os mesmo em: Com Risco (CR); Pode Causar Risco (PCR) e Sem Risco (Tabela 4).

Tabela 4. Características físicas da rodovia

\begin{tabular}{|c|c|c|c|}
\hline \multicolumn{4}{|c|}{ PASSIVOS AMBIENTAIS } \\
\hline LOCALIZACCÃO & $\mathbf{N}^{0}$ & PROJETO & OBSERVAÇ̃̃ES \\
\hline 88+470 LD e LE & OU-01 & $\begin{array}{l}\text { Hidrossemeadura; paisagismo } \mathrm{e} \\
\text { remoção de placas de publicidade }\end{array}$ & $\begin{array}{l}\text { Executado.A retirada das } \\
\text { placas de publicidade na faixa } \\
\text { non edificandi }\end{array}$ \\
\hline $88+370 \mathrm{LE}$ & TE-02 & $\begin{array}{l}\text { Sinalização; ordenamento dos } \\
\text { acessos/canteiros. Parecer do } \\
\text { projetista: não havendo espaço } \\
\text { execução de tapers, o que foi } \\
\text { executado fica considerado como } \\
\text { atendido a recuperação deste PA }\end{array}$ & $\begin{array}{l}\text { Executado redutor de } \\
\text { velocidade, parada de ônibus } \\
\text { e sinalização }\end{array}$ \\
\hline $88+150 \mathrm{LD}$ & OU-03 & $\begin{array}{l}\text { Banqueta de aterro; Ddescida } \\
\text { d'agua; defensa metálica. Parecer da } \\
\text { projetista: em razão do executado, ñ } \\
\text { PA. }\end{array}$ & $\begin{array}{lll}\text { Executado } & \text { acesso } & \mathrm{e} \\
\text { sinalização } & & \end{array}$ \\
\hline $88+910 \mathrm{LE}$ & $\mathrm{CO}-04$ & $\begin{array}{l}\text { Recomposição talude; } \\
\text { hidrossemeadura, sarjeta de corte }\end{array}$ & Executado \\
\hline 84+830 LD & $\mathrm{CO}-05$ & Hidrossemeadua & Executado \\
\hline $84+270 \mathrm{LD}$ & $\mathrm{CO}-06$ & Hidrossemeadura & Executado \\
\hline $83+750 \mathrm{LD}$ & OU-LD & $\begin{array}{l}\text { Banqueta de aterro; descida d'água; } \\
\text { defensa metálica. Parecer da } \\
\text { projetista: em razão do executado ñ } \\
\text { PA. }\end{array}$ & $\begin{array}{l}\text { Executada interseção de } \\
\text { acesso com ajardinamento } \\
\text { dos canteiros e sinalização }\end{array}$ \\
\hline $83+750 \mathrm{LE}$ & CE-08 & $\begin{array}{l}\text { Hidrossemeadura; plantação de } \\
\text { arbusto }\end{array}$ & $\begin{array}{l}\text { Hidrossemeado executada nos } \\
\text { taludes.Na área plana o } \\
\text { proprietário } \\
\text { reflorestamento com pinus. }\end{array}$ \\
\hline $80+270 \mathrm{LD}$ e LE & OU-09 & Corte e remoção de árvores & Executado \\
\hline 79+550 LD e LE & OU-10 & $\begin{array}{l}\text { Remoção; guarda-corpo; defensa; } \\
\text { hidrossemeadura; arbusto }\end{array}$ & $\begin{array}{l}\text { Executado. A vegetação } \\
\text { natural existente torna } \\
\text { desnecessário } \\
\text { Hidrossemeado. }\end{array}$ \\
\hline $79+270 \mathrm{LE}$ & $\mathrm{CO}-11$ & Hidrossemeadura & $\begin{array}{l}\text { Executado. Parte do corte o } \\
\text { material é de folhelho, Class. } \\
\text { Em } 2^{\mathrm{a}} \text { categoria }\end{array}$ \\
\hline
\end{tabular}




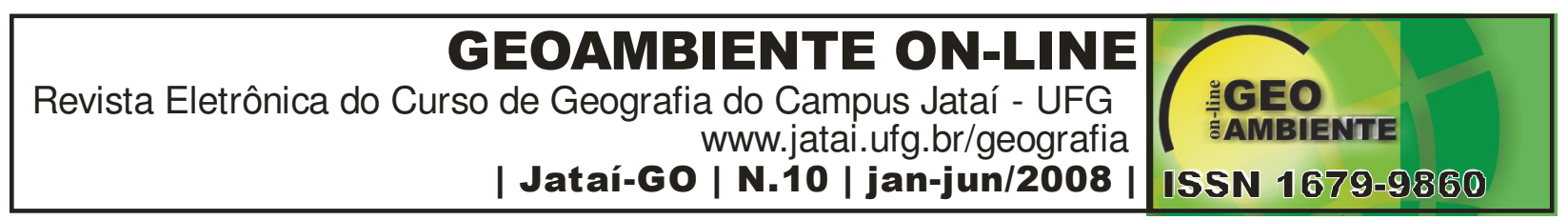

\begin{tabular}{|c|c|c|c|}
\hline 77+930 LE & $\mathrm{CO} 12$ & $\begin{array}{l}\text { Hidrossemeadura; valeta de crista de } \\
\text { corte }\end{array}$ & Executado \\
\hline $75+710 \mathrm{LD}$ & AT-13 & $\begin{array}{l}\text { Banqueta de aterro; descida d'água; } \\
\text { hidrossemeadura }\end{array}$ & $\begin{array}{l}\text { Aterro recomposto, } \\
\text { hidrossemeado e banquetas de } \\
\text { aterros executados }\end{array}$ \\
\hline $75+110 \mathrm{LE}$ & $\mathrm{CO}-14$ & $\begin{array}{l}\text { Retaludamento; vala de crista; } \\
\text { hidrossemeadura; sarjeta e arbusto }\end{array}$ & $\begin{array}{l}\text { Executado.Hidrossemeado } \\
\text { desnecessária, vegetação } \\
\text { natural existente }\end{array}$ \\
\hline $72+990 \mathrm{LD}$ & AT-15 & $\begin{array}{l}\text { Banqueta } \text { de } \\
\text { hidrossemeadura e caixa coletora }\end{array}$ & Executado \\
\hline $72+830 \mathrm{LE}$ & $\mathrm{CO}-16$ & Hidrossemeadura & Confomado e hidrossemeado \\
\hline 72+470 LD & OU-17 & $\begin{array}{l}\text { Banqueta aterro; defensa metálica. } \\
\text { Parecer do Projetista: supressão } \\
\text { deste Passivo Ambiental }\end{array}$ & $\begin{array}{l}\text { Pendência entre o DEINFRA } \\
\text { e o proprietário (lindeiro). }\end{array}$ \\
\hline $72+310$ LD e LE & OU-18 & \begin{tabular}{lrr} 
Guarda & Corpo & \multicolumn{2}{c}{ Defensas; } \\
Sinalização; & Plantação & de \\
Árvores/arbustos & & \\
\end{tabular} & $\begin{array}{l}\text { Guarda corpo, defensas, } \\
\text { arvores e arbustos executados }\end{array}$ \\
\hline $72+150 \mathrm{LE}$ & CO-19 & $\begin{array}{lcc}\text { Vala de } & \text { crista } & \text { corte; } \\
\text { hidrossemeadura } & & \end{array}$ & $\begin{array}{l}\text { Cobertura vegetal existente é } \\
\text { suficiente. Não é necessária } \\
\text { vala }\end{array}$ \\
\hline $71+910 \mathrm{LE}$ & AT-20 & $\begin{array}{l}\text { Acostamento; } \\
\text { condução }\end{array}$ & Executado \\
\hline $72+270 \mathrm{LD}$ & OU-21 & $\begin{array}{l}\text { Conformação; Hidrossemeadura; } \\
\text { Travessia; Arbustos }\end{array}$ & Executados \\
\hline $72+270 \mathrm{LE}$ & $\mathrm{CO}-22$ & $\begin{array}{l}\text { Retaludamento; Hidrossemeadura; } \\
\text { sarjeta; arbustos; Corte de arvores. } \\
\text { Parecer do projetista: talude estável; } \\
\text { árvores em afatamento seguro em } \\
\text { relação a pista. }\end{array}$ & $\begin{array}{l}\text { Executados: } \mathrm{o} \text { valetão } \mathrm{e} \\
\text { hidrossemeadura e arbustos. }\end{array}$ \\
\hline $65+950 \mathrm{LE}$ & OU-23 & $\begin{array}{l}\text { Defença New Jersey } \\
\text { Hidrossemeadura; Sinalização; } \\
\text { Plantio de árvores/arbustos. Parecer } \\
\text { do Projetista: A execução de redutor } \\
\text { de velocidade, próximo ao posto } \\
\text { (PRE) e a falta de espaço para } \\
\text { acesso de caminhões nas } \\
\text { proximidades da (CASAN) torna } \\
\text { inviável a execução de defensa tipo } \\
\text { New Jersey. Suprimido o Passivo } \\
\text { Ambiental. }\end{array}$ & $\begin{array}{l}\text { Executado: } \quad \text { defensas, } \\
\text { sinalização; árvores e } \\
\text { arbustos }\end{array}$ \\
\hline $65+910 \mathrm{LE}$ & TE-24 & Hidrossemeadura & Ejecutada \\
\hline $65+790 \mathrm{LD}$ & $\mathrm{CO}-25$ & $\begin{array}{l}\text { Retaludamento; Hidrossemeadura; } \\
\text { sarjeta de corte }\end{array}$ & Executados \\
\hline $64+750 \mathrm{LE}$ & $\mathrm{CO}-26$ & 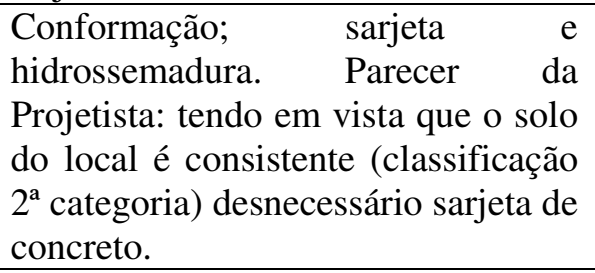 & $\begin{array}{l}\text { Executados:reconformação, } \\
\text { valetão e hidrossemeadura }\end{array}$ \\
\hline $\begin{array}{l}65+470 \text { a } 65+800 \\
\text { LD e LE }\end{array}$ & NU-26a & Passagem urbana; Palmeira & $\begin{array}{l}\text { Executados: acostamento e } \\
\text { trevo }\end{array}$ \\
\hline
\end{tabular}




\begin{tabular}{|c|c|}
\hline $\begin{array}{r}\text { GEOAMBIENTE ON-LINE } \\
\text { Revista Eletrônica do Curso de Geografia do Campus Jataí - UFG } \\
\text { www.jatai.ufg.br/geografia } \\
\text { | Jataí-Go | N.10 | jan-jun/2008 | }\end{array}$ & 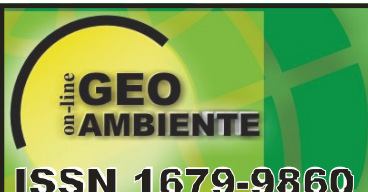 \\
\hline
\end{tabular}

\begin{tabular}{|c|c|c|c|}
\hline 64+110 LD e LE & OU-27 & $\begin{array}{l}\text { Guarda corpo; Defensas; } \\
\text { Sinalização; } \\
\text { árvores/arbustos e hidrossemeadura }\end{array}$ & $\begin{array}{l}\text { Executados: } \\
\text { hidrossemeadura, guarda } \\
\text { corpo, defensa, e sinalização. } \\
\text { Faltaram plantio de } \\
\text { árvores/arbustos. }\end{array}$ \\
\hline $64+070 \mathrm{LE}$ & TE-28 & $\begin{array}{l}\text { Refazer Tapume; hidrossemeadura; } \\
\text { arbusto. Parecer do Projetista: a } \\
\text { ausência de focos erosivos, elimina } \\
\text { o Passivo Ambiental. }\end{array}$ & $\begin{array}{l}\text { Executados: arbustos } \mathrm{e} \\
\text { hidrossemeado. }\end{array}$ \\
\hline 63+950 LD e LE & $\mathrm{CO}-29$ & Hidrossemeadura & $\begin{array}{l}\text { Corte de solo classificado em } \\
2^{\text {a }} \text { categoria; cfme } \\
\text { fiscalização: desnecessário } \\
\text { hidrossemeadura }\end{array}$ \\
\hline $63+910 \mathrm{LE}$ & TE-30 & $\begin{array}{l}\text { Refazer Tapume; Hidrossemeadura; } \\
\text { arbustos }\end{array}$ & Executados \\
\hline $63+590 \mathrm{LE}$ & CO-31 & Hidrossemadura & Executada \\
\hline $63+590 \mathrm{LD}$ & $\mathrm{CO}-32$ & $\begin{array}{lccc}\text { Vala } & \text { de } & \text { crista } & \text { corte; } \\
\text { hidrossemeadura; } & \text { arbustos }\end{array}$ & Executados \\
\hline $63+230 \mathrm{LD}$ & CE-33 & $\begin{array}{ll}\text { Relatudamento; } & \text { Sarjeta; } \\
\text { hidrossemeadura; arbustos } & \\
\end{array}$ & Executados \\
\hline $63+150 \mathrm{LE}$ & TE-34 & $\begin{array}{l}\text { Remoção de material; } \\
\text { Hidrossemeadura; arbustos }\end{array}$ & Executados \\
\hline $62+750 \mathrm{LD}$ & $\mathrm{CO}-35$ & $\begin{array}{l}\text { Sarjeta de corte; hidrossemeadura; } \\
\text { plantio de arbustos }\end{array}$ & 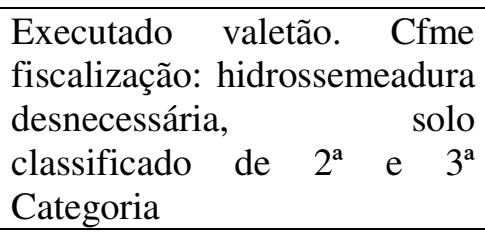 \\
\hline $58+350 \mathrm{LE}$ & TE-37 & $\begin{array}{l}\text { Recoformação de talude; plantio de } \\
\text { árvores/arbustos }\end{array}$ & Executados. \\
\hline $58+350 \mathrm{LD}$ & $\mathrm{CO}-38$ & Hidrossemeadura & Executada \\
\hline $58+310 \mathrm{LE}$ & CO-39 & Hidrossemeadura & Executada \\
\hline $58+270 \mathrm{LE}$ & TE-40 & $\begin{array}{l}\text { Retaludamento; hidrossemeadura; } \\
\text { plantio de árvores/arbustos }\end{array}$ & Executados \\
\hline $57+270 \mathrm{LD}$ e LE & OU-41 & $\begin{array}{l}\text { Guarda-corpo; sinalização; plantio } \\
\text { de árvores/arbustos; }\end{array}$ & Executados \\
\hline $56+030 \mathrm{LD}$ & $\mathrm{CO}-42$ & $\begin{array}{l}\text { Hidrossemeadura; } \text { plantio } \mathrm{de} \\
\text { árvores/arbustos }\end{array}$ & Executados \\
\hline $55+990 \mathrm{LE}$ & $\mathrm{CO}-43$ & $\begin{array}{l}\begin{array}{l}\text { Hidrossemeadura; } \\
\text { arbustos }\end{array} \\
\end{array}$ & Executados \\
\hline $55+910 \mathrm{LE}$ & TE-44 & $\begin{array}{llr}\text { Reconformação } & \text { da } & \text { área; } \\
\text { hidrossemeadura; } & \text { plantio } & \text { de } \\
\text { árvores/arbustos } & & \\
\end{array}$ & Executados \\
\hline $55+830 \mathrm{LD}$ & $\mathrm{CO}-45$ & $\begin{array}{l}\begin{array}{l}\text { Hidrossemeadura; } \\
\text { forrações/arbustos }\end{array} \\
\end{array}$ & Executados \\
\hline $55+790 \mathrm{LE}$ & TE-46 & $\begin{array}{l}\text { Hidrossemeadura; } \\
\text { plantio/árvores/arbustos/forrações }\end{array}$ & Executados \\
\hline $\begin{array}{l}52+750 \text { a } 52+830 \\
\text { LD e LE }\end{array}$ & NU-47 & $\begin{array}{l}\text { Travessia urbana de Otacílio Costa: } \\
\text { urbanização da extensão. }\end{array}$ & $\begin{array}{l}\text { Executados: } \\
\text { Terceira Pista, ciclovias, } \\
\text { calçadas, redutores de } \\
\text { velocidade, } \\
\text { enleivamento, }\end{array}$ \\
\hline
\end{tabular}




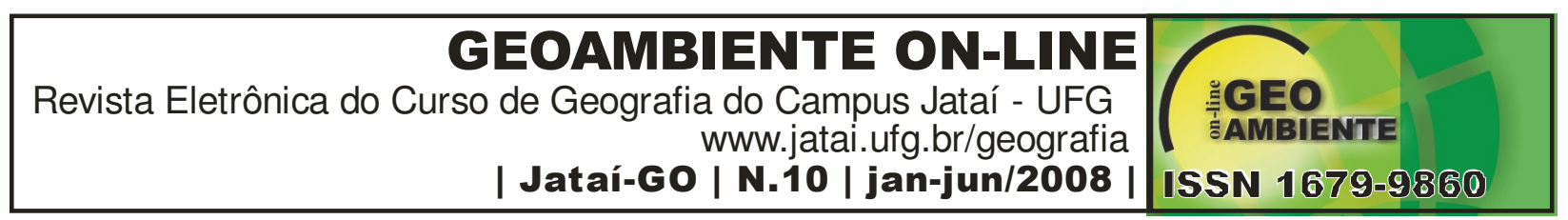

\begin{tabular}{|c|c|c|c|}
\hline & & & árvores/arbustos/forrações. \\
\hline $55+630 \mathrm{LE}$ & TE-48 & \begin{tabular}{lrr}
\multicolumn{2}{l}{ Retaludamento; } & \multicolumn{2}{l}{ hidrossemeadura; } \\
vala de & crista; & plantio \\
árvores/arbustos & &
\end{tabular} & Executados \\
\hline $55+550 \mathrm{LE}$ & AT-49 & $\begin{array}{l}\text { Reconformação de voçoroca; plantio } \\
\text { árvores/arbustos; sarjetas;banquetas; } \\
\text { descida d'água. }\end{array}$ & Executados \\
\hline $54+750 \mathrm{LE}$ & TE-50 & Conformação de aterro & Executado \\
\hline $54+710 \mathrm{LD}$ & TE-51 & $\begin{array}{l}\text { Retaludamento; muro e revestimento } \\
\text { vegetal }\end{array}$ & $\begin{array}{l}\text { Executados: retaludamento, } \\
\text { hidrossemeadura. Área de } \\
\text { desapripriação }\end{array}$ \\
\hline $54+590 \mathrm{LE}$ & TR-52 & Revestimento vegetal & $\begin{array}{l}\text { Executados:Valeta } \\
\text { revestimento vegetal }\end{array}$ \\
\hline $52+670 \mathrm{LD}$ & TE-53 & $\begin{array}{l}\text { Reconformação; hidrossemeadura; } \\
\text { plantio de árvres/arbustos }\end{array}$ & Executados \\
\hline $52+670 \mathrm{LE}$ & TE-54 & $\begin{array}{l}\text { Trevo; drenagem; reconformação de } \\
\text { erosão; hirossemeadura; plantio de } \\
\text { árvores/arbustos }\end{array}$ & Executados \\
\hline $51+150$ LD e LE & OU-55 & $\begin{array}{lll}\text { Defensa; } & \text { plantio } & \mathrm{de} \\
\text { árvores/arbustos/ forrações } & \end{array}$ & $\begin{array}{l}\text { Executado defensa. Mata } \\
\text { ciliar existente, suficiente. }\end{array}$ \\
\hline $50+630 \mathrm{LD}$ & CE-56 & Hidrossemeadura e arbustos & $\begin{array}{l}\text { Executado plantio de } \\
\text { arbustos; } \\
\text { desnecessária. }\end{array}$ \\
\hline $46+990 \mathrm{LD}$ & AT-57 & $\begin{array}{lr}\text { Banqueta de } & \text { condução } \\
\text { hidrossemeadura; } & \text { conformação; } \\
\text { plantio de arbustos. } & \\
\end{array}$ & Executados. \\
\hline $45+790 \mathrm{LD}$ & OU-58 & Travessia de pedestre; sinalização; & Executados \\
\hline $45+070 \mathrm{LD}$ & CO-59 & $\begin{array}{lrrr}\text { Trevo; vala } & \text { de } & \text { crista; } \\
\text { hidrossemeadura }\end{array}$ & Executados \\
\hline $44 * 630$ LD TE-60 & TE-60 & $\begin{array}{l}\text { Sarjeta; passagem de sarjeta; } \\
\text { hidrossemeadura. } \\
\text { projetista: por tratar-se de solo com } \\
\text { classificação de } 2^{\text {a }} \text { categoria, não } \\
\text { houve necessidade de sarjeta de } \\
\text { concreto }\end{array}$ & Executado valetão lateral \\
\hline $44+340 \mathrm{LD}$ & TE-61 & $\begin{array}{l}\text { Sarjeta; passagem de sarjeta; } \\
\text { arbustos; hidrossemeadura. Parecer } \\
\text { do projetista: por trata-se de solo } \\
\text { classificado de } 2^{\mathrm{a}} \text { categoria não } \\
\text { houve necessidade de sarjeta de } \\
\text { concreto no local }\end{array}$ & Executado valetão lateral \\
\hline 43+910 LD & $\mathrm{CO}-62$ & $\begin{array}{l}\text { Hidrossemeadura; plantio } \\
\text { árvores/arbusto/forrações }\end{array}$ & Executados \\
\hline $42+750 \mathrm{LD}$ & CO-63 & $\begin{array}{l}\text { Hidrossemeadura; } \\
\text { plantioárvores/arbustos/forrações }\end{array}$ & Executados \\
\hline $39+710 \mathrm{LD} / \mathrm{LE}$ & OU-64 & $\begin{array}{l}\text { Guada-corpo; defensa; plantio de } \\
\text { árvores/arbustos/forrações }\end{array}$ & Executados \\
\hline $38+670 \mathrm{LE}$ & OU-85 & $\begin{array}{l}\text { Passagem em valetão; escavação de } \\
\text { valas }\end{array}$ & $\begin{array}{l}\text { Executados: valetão } \\
\text { hidrossemeadura }\end{array}$ \\
\hline $37+310 \mathrm{LE}$ & CE-66 & Hidrossemeadura; arbusto & $\begin{array}{l}\text { Executados: valetão } \\
\text { hidrossemeadura }\end{array}$ \\
\hline
\end{tabular}




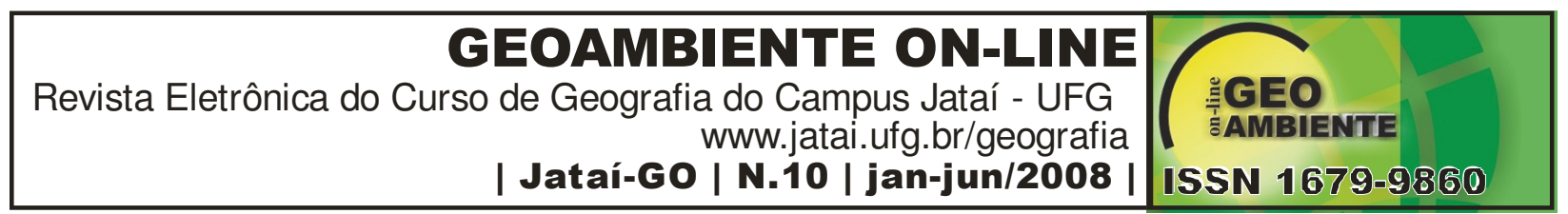

\begin{tabular}{|c|c|c|c|}
\hline $37+310 \mathrm{LD}$ & CO-67 & $\begin{array}{l}\text { Hidrossemeadura;plantio } \\
\text { árvores/arbustos }\end{array}$ & Executados \\
\hline $35+990 \mathrm{LD} / \mathrm{LE}$ & CO-68 & $\begin{array}{l}\text { Vala de crista } \\
\text { hidrossemeadura }\end{array}$ & Executados \\
\hline $35+910 \mathrm{LE}$ & TE-69 & $\begin{array}{l}\text { Meio fio; plantio de } \\
\text { árvores/arbustos/leivas. Parecer do } \\
\text { projetista: parada de ônibus com a } \\
\text { falta de espaço para tapers, } \\
\text { suprimiu-se canteiro central }\end{array}$ & Executados \\
\hline $33+200(\mathrm{PF})$ & TE-71 & $\begin{array}{lr}\text { Remção de entelhos; relocação } & \text { de } \\
\text { casas; plantio } & \text { de } \\
\text { árvores/arbustos/forração } & \text { e } \\
\text { hidrossemeadura } & \end{array}$ & $\begin{array}{l}\text { As casas foram removidas; } \\
\text { área reconformada e } \\
\text { hidrossemeada. Conforme } \\
\text { fiscalização outros serviços } \\
\text { desnecessários }\end{array}$ \\
\hline $33+200(\mathrm{PF})$ & OU-72 & $\begin{array}{l}\text { Trevo de interseção com a BR } 470 \text { : } \\
\text { sinalização e enleivamento nos } \\
\text { canteiros }\end{array}$ & Executados \\
\hline
\end{tabular}

\section{3 - Medidas educativas e de segurança}

Ao longo da rodovia foram aplicadas diversas medidas educativas e de segurança tais como: passarelas provisórias em madeira para os pedestres, faixas sinalizadoras padrão tipo "bannes" para delimitação de áreas em execução nas interseções, caixas coletoras, acessos a galerias. Foram executados redutores de velocidade os quais disciplinam a velocidade dos veículos, abrigos de ônibus padrão DETER e corte de árvores exóticas às margens da rodovia. A sinalização da rodovia foi incrementada com diversas placas educativas sobre o meio ambiente.

\section{4 - Projeto paisagismo}

O projeto paisagístico foi alterado (Tabela 5), visando melhor adaptação das árvores, dos arbustos e forrações, em função do clima predominante na região serrana e a disponibilidade de mudas nos viveiros além de apresentarem baixos custos e de fácil manutenção.

Tabela 5. Espécies de árvores utilizadas no projeto paisagístico

\begin{tabular}{|l|c|l|}
\hline Projeto SOTEPA & & Projeto ECOPLAN \\
\hline Canela Lageana & $\Rightarrow$ & Canela Lageana \\
\hline Canela Amarela & $\Rightarrow$ & Orticeira \\
\hline Canela Guaica & $\Rightarrow$ & Uva do Padre \\
\hline Canela de Fogo & $\Rightarrow$ & Canela Branca \\
\hline Canela Fedida & $\Rightarrow$ & Canela Branca \\
\hline
\end{tabular}




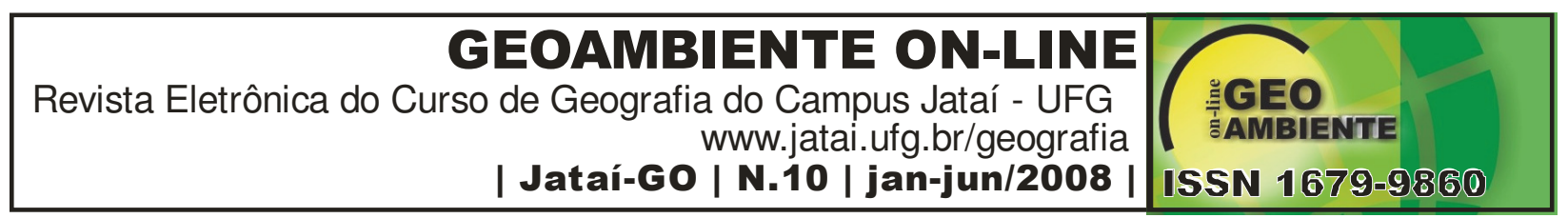

\begin{tabular}{|c|c|c|}
\hline Camboaté & $\Rightarrow$ & Angico \\
\hline Guaramirim & $\Rightarrow$ & Ipê Roxo, Ipê amarelo \\
\hline Pimenteira & $\Rightarrow$ & Legustro \\
\hline Araucária & $\Rightarrow$ & Araucária \\
\hline Guarobirobeira & $\Rightarrow$ & Guarabirobeira \\
\hline Pessegueiro Brabo & $\Rightarrow$ & Calistomã \\
\hline Acaçazeiro & $\Rightarrow$ & Araçazeiro \\
\hline Bracatinga & $\Rightarrow$ & Acácia Negra \\
\hline Chorão & $\Rightarrow$ & Canafistola \\
\hline Pitanga & $\Rightarrow$ & Pitanga \\
\hline Arbusos e Forrações & & Arbustos e Forrações \\
\hline Esponjina & $\Rightarrow$ & Sarandi \\
\hline Cássia Dourada & $\Rightarrow$ & Cássia Negra \\
\hline Azaléia & $\Rightarrow$ & Azaléia \\
\hline Hibisco & $\Rightarrow$ & Cedro Geminho \\
\hline Hortência & $\Rightarrow$ & Hortência \\
\hline Ligusto Arbustivo & $\Rightarrow$ & Ligusto Arbustivo \\
\hline Sálvia & $\Rightarrow$ & Sálvia \\
\hline Amor Perfeito & $\Rightarrow$ & Tagete \\
\hline Espada de São Jorge & $\Rightarrow$ & Lírio \\
\hline Piteira Azul & $\Rightarrow$ & Manacá de Cheiro \\
\hline Casca D’água & $\Rightarrow$ & Hortência \\
\hline Vacunzeiro & $\Rightarrow$ & Jasmim \\
\hline Vedélia & $\Rightarrow$ & Jasmim \\
\hline Bambu & $\Rightarrow$ & Bambu \\
\hline Caúnas & $\Rightarrow$ & Hortência \\
\hline
\end{tabular}

\section{4 - Conclusões}

Em obras rodoviárias, as intervenções acontecem de forma agressiva, em relação ao meio ambiente. O relevo, a vegetação, os cursos d'água e populações, sofrem alterações, supressões e desvios. Para minimizar ou reparar os danos causados ao Meio Ambiente, várias ações são implementadas no sentido de recompor o estado natural ou menos degradante.;

Para obter o resultado desejado, o DEINFRA, mediante a elaboração de projetos, aplicação de normas de proteção ambiental e através do seu corpo técnico, empresas contratadas imprime medidas ou procedimentos adequados para a preservação do Meio Ambiente;

Entre os serviços desenvolvidos destaca-se a recuperação dos Passivos Ambientais e as medidas de segurança aplicados em prol do usuário, durante e a posterior a execução da obra;

Também não podemos deixar de assinalar, que foram objetos de atenção, o cumprimento das determinações legais, através dos respectivos licenciamentos e instruções ambientais do DEINFRA; 


\section{GEOAMBIENTE ON-LINE \\ Revista Eletrônica do Curso de Geografia do Campus Jataí - UFG www.jatai.ufg.br/geografia \\ | Jataí-GO | N.10 | jan-jun/2008 \\ CEO \\ БMMBIENTE \\ ISSN 1679-9860}

Outros benefícios advindos da execução da obra, tais como: acessos melhorados, redutores de velocidades, dispositivos de segurança, melhoramentos que, de alguma forma, influíram em índices e satisfação dos usuários e população lindeiras. Porém, observou-se que, ao longo da rodovia, em algumas propriedades e perímetros urbanos, permaneceram as ocupações da faixa de domínio

Recomenda-se para futuras intervenções, a implantação de uma faixa de domínio com larguras entre 60 e 100 metros ampliando,desta forma, o espaço necessário, principalmente, nos perímetros urbanos das cidades de Otacílio Costa e Palmeiras, com objetivo de facilitar a execução de melhoramentos: dos trevos de acessos, rodovias marginais, canteiros e outras obras de apoio aos usuários da rodovia. Também com a finalidade de evitar que o excesso de ruídos afetem os moradores das margens da rodovia.

\section{5 - Referências Bibliográficas}

BRASIL. Departamento Nacional de Infra-estrutura. Publicação IPR - 070 - Manual de conservação rodoviária. 565p. 2005.

DEINFRA. Departamento Estadual de Infra Estrutura. República Federativa do Brasil. Governo do Estado de Santa Catarina. Secretaria de Estado da infra-Estrutura. Rodovia. SC. 425. Trecho BR 470 - Otacílio Costa - BR 282. Relatório de Controle Ambiental. Florianópolis. Ago. 2003.

DUTRA, B.S.L; BECEGATO, V.A. \& FIGUEIREDO, O.A.R. Impacto Ambiental: Levantamento dos passivos ambientais na BR 282 Trecho Lages (SC) e São José do Cerrito (SC). Geoambiente on-line N.8. p. 104-133. 2007

FOGLIATTI, M.C; FILIPPO, S. \& GOUDARD, B. Avaliação de Impactos Ambientais. Aplicação aos Sistemas de Transporte. Interciência. 2004.

MORALES, P.R.D. Prefácio. In: BELLIA, V. et al. Introdução à gestão ambiental de estradas. Rio de Janeiro: IME/FRF, 2005. 160p.

PARANÁ. Departamento de Estradas de Rodagem. Manual de instruções ambientais para obras rodoviárias. 2000.

SANTA CATARINA, Secretaria de Estado dos Transportes de Obras. Departamento de Estradas de Rodagem. Projeto BID (BR 0355): Programa Rodoviário de Santa Catarina Etapa IV. Treinamento em Meio Ambiente, FLORIANÒPOLIS, Março de 2002. DER/ 


\section{GEOAMBIENTE ON-LINE}

Revista Eletrônica do Curso de Geografia do Campus Jataí - UFG www.jatai.ufg.br/geografia | Jataí-GO | N.10 | jan-jun/2008 |

ISSN 1679-9860

Consorcio APPE / PRIME. Disponível em: <www.deinfra.sc.gov.br>. Acesso em: 18 mar 2006. 